\title{
Inhibition of Cell Cycle and Induction of Apoptosis y Ethanol Leaves Extract of Chrysanthemum cinerariifolium (Trev.) In T47D Breast Cancer Cells
}

\author{
Roihatul Mutiah ${ }^{1}$, Alfiyah Laily Inayatinn ${ }^{1}$, Rahmi Annisa ${ }^{1}$, Yen Yen Ari Indrawijaya ${ }^{1}$, Anik Listiyana ${ }^{2}$
}

1. Department of Pharmacy, Faculty of Medical and Health Sciences, Maulana Malik Ibrahim State Islamic University of Malang Indonesia, East Java Indonesia 65144

2. Department of Medical, Faculty of Medical and Health Sciences, Maulana Malik Ibrahim State Islamic University of Malang Indonesia, East Java Indonesia 65144

\begin{tabular}{l} 
Info Article \\
\hline Submitted: $04-10-2019$ \\
Revised: $29-02-2020$ \\
Accepted: $20-04-2020$ \\
*Corresponding author \\
Roihatul Mutiah \\
Email: \\
roiha@farmasi.uin- \\
malang.ac.id
\end{tabular}

\begin{abstract}
Chrysanthemum cinerariifolium (C.cinerariifolium) is a plant of the Asteraceae family, which has been applied by the community as an ornamental plant and traditional medicine. In this study, the effect of $C$. cinerariifolium leaves extract on inhibition of cell cycle and induction of apoptosis in T47D breast cancer cells was tested and compared to the standard chemotherapy agent. The citotoxic activity of $C$. cinerariifolium leaves extract against T47D cancer cells and Vero normal cells was tested by MTT method. Profile of apoptosis and cell cycle were observed by flow cytometry method. Based on chemical compounds profil which is tested used TLC showed that C.cinerariifolium leaves extracts contained flavonoid and terpenoid chemical compounds. The result of cytotoxic test showed that leaves extract of $C$. cinerariifolium was able to inhibit the growth of T47D cancer cell at $\mathrm{IC}_{50} 418.8 \mu \mathrm{g} / \mathrm{mL}$. Doxorubicin, extracted from Streptomyces peucetius used as treatment in several cancers including breast cancer. Doxorubicin could inhibit the growth of T47D cancer cells in $115.1 \mu \mathrm{g} / \mathrm{mL}$. The results of cell cycle analysis showed that the $C$. cinerariifolium leaves extract inhibited cell cycle in G0-G1 and S phase, whereas doxorubicin was able to inhibit cell cycle in G0-G1 phase but experienced cell accumulation in G2-M phase. The percentage of apoptosis in cycle was showed in M1 (sub G1) and M5 (multinuclear) phase which treatment of $C$. cinerariifolium leaves extract was higher than doxorubicin. Therefore, $C$. cinerariifolium leaves extract has potential activity as anticancer agent causes inhibition of cell cycle and induction apoptosis.
\end{abstract}

Keywords: Chrysanthemum cinerariifolium, apoptosis, cell cycle, T47D cells

\section{INTRODUCTION}

Breast cancer is a malignancy that occurs in cells contained in breast tissue, and both derived from the components of the glands (ductal epithelial or globulus) and those derived from components other than glands such as tissue nerves in the breast, fat tissue, and blood vessels (Sari et al., 2017). American Cancer Society revealed in its latest data that by the year 2013, every year there are about 39,620 women died caused by breast cancer (DeSantis et al., 2014).

Breast cancer treatment efforts such as the use of chemotherapy agents, radiation, radiotherapy has widely used. Doxorubicin is a chemotherapy drug widely used in the treatment of breast cancer. However, the use of chemotherapy drugs is decreased because of the risk of side effects that often occur, such as resistance and cardiomyopathy (Octavia et al., 2012). Therefore, to minimize the occurrence of side effects used traditional medicine using herbs. One of them is chrysanthemum (Chrysanthemum cinerariifolium). Crhysanthemum cinerariifolium (C. cinerariifolium) is a plant of the Asteraceae family that has been used by the community as an ornamental plant because of its beautiful flowers. Various plant organs can utilized as drugs such as antibacterial, anti-inflammatory, allergy, and also anticancer (Grdisa et al., 2009). Based on previous 
research indicates that the extract of Chrysanthemum zawadskii flower and leaves has pharmacological activity, is as an antiinflammatory by inhibition of lipopolysaccharide on RAW264.7 cell induced by nitrite oxide (Kim et al., 2012).

The previous study showed that Chrysanthemum contain terpenoid compounds, flavonoids, and derivatives that are suspected of having anticancer activity (Ukiya et al., 2002). Previous research has also reported that C. cinerariifolium comprises a quercetin compound (Jeong et al., 2012; Alviana et al., 2016). The quercetin compound is thought to have an anticancer effect through the induction of the p21 gene which is a CDK inhibitor, along with a decline in $\mathrm{Rb}$ gene that inhibits cell cycle in G1 / S phase by inhibiting E2F (Yerlikaya et al., 2017).

Scientific evidence of anticancer activity of chrysanthemum plants with $C$. cinerarifolium species has not widely performed in both apoptotic and cell cycle testing. In this study reported the effects of $C$. cinerariifolium extract on apoptosis induction and regulation of breast cancer cell cycle T47D.

\section{MATERIAL AND METHODS}

The materials used in this study were $C$. cinerariifolium leaves, $96 \%$ ethanol, distilled water, n-Hexane p. a, ethyl acetate p.a, $10 \% \mathrm{H}_{2} \mathrm{SO}_{4}$, T47D cells and Vero cells obtained from Parasitology Laboratory Faculty of Medicine Gajah Mada University, Yogyakarta, Complete Medium (CM) RPMI 1640 (Gibco, Invitrogen Canada), CM MI99 (Gibco, Invitrogen Canada), PBS, Trypsin-EDTA, DMSO (EMSURE ACS, Japan), SDS (Merck, Berlin Germany), doxorubicin HCL $50 \mathrm{mg}$, MTT solution (Bio Basic Inc, Canada), trypsin-EDTA 0,25\% (Gibco, Invitrogen Canada), RNAse (Gibco, Invitrogen Canada), propidium iodide (SigmaAldrich, USA), triton-X (pro GC Merck, Berlin, Germany) and Annexin V (Sigma-Aldrich, USA).

\section{Plant determination}

C. cinerariifolium (Trev.) plants were obtained from Nongkojajar, Pasuruan, East Java, Indonesia. Determination of $C$. cinerariifolium plant was conducted in Materia Medika Integrated Service Unit Batu City, East Java, Indonesia.

\section{Ethical approval}

This study has received ethical approval No. 002/EC/KEPK-FKIK/2018 from Medical Research Ethics Committee of Faculty of Medicine and Health
Sciences Maulana Malik Ibrahim State Islamic University of Malang.

\section{Sample preparation}

Samples of $C$. cinerariifolium were harvested by cutting on the leaves using scissors. Then begins by sorting each section, washed, dried under the sun, and final sorting. Dry samples are mashed up with grinding machines and weighed $C$. cinerariifolium leaves powder.

\section{Extraction of $\boldsymbol{C}$. cinerariifolium}

Leaves powder of $C$. cinerariifolium was put into the Erlenmeyer flask and $96 \%$ ethanol solvent was added with a ratio of 1: 20 . Then extracted using UAE (Ultrasonication Assisted Extraction) for 2 min with three replications. The leaves filtrate $C$. cinerariifolium of the UAE evaporated the solvent using a rotary evaporator at $50^{\circ} \mathrm{C}$ temperature to produce a crude extract. The sticky extract was concentrated using an oven at $40^{\circ} \mathrm{C}$ temperature until the texture of the extract became concentrated. Then calculated extracted yield using the formula:

Extracted yield $=\frac{\text { Extract weight }}{\text { Raw material weight }} \times 100 \%$

\section{Identification of compounds used Thin Layer Chromatography (TLC)}

In the identification of compounds, the silica gel 60 F254 used as a stationary phase with the n-Hexane p. a (Merck, Berlin, Germany) and ethyl acetate p.a (Merck, Berlin, Germany) (8: 2) periods of motion. The stain used was $10 \% \mathrm{H}_{2} \mathrm{SO}_{4}$. Identify stain compounds using Thin Layer Chromatography (TLC) Visualizer.

\section{Sample preparation for anticancer activity and toxicity test}

Leaves extract was weighed as much as $10 \mathrm{mg}$, dissolved with $100 \mu \mathrm{g} / \mathrm{mL}$ DMSO and made seven serial concentrations in T47D cells were $1000 ; 800 ; 600 ; 400 ; 200 ; 100 ; 50 \mu \mathrm{g} / \mathrm{mL}$ and in Vero cells were $1000 ; 500 ; 250 ; 125 ; 62,5 ; 31,25$; $15.625 \mu \mathrm{g} / \mathrm{mL}$. While doxorubicin positive control was made seven serial concentrations, in T47D cells were $1087.04 ; 543.52 ; 271.76 ; 135.88 ; 67.94$; $33.97 ; 16.985 \mu \mathrm{g} / \mathrm{mL}$ and in Vero cells were 5435 ; 2717.60; 1358.80; 679.40; 339.70; 169.85; 84,925 $\mu \mathrm{g} / \mathrm{mL}$.

\section{Anticancer activity and toxicity test}

An anticancer activity test conducted in T47D cell culture with RPMI 1640 medium (Gibco, 
Invitrogen Canada). Furthermore, toxicity test performed in Vero cell culture used the M199 medium (Gibco, Invitrogen Canada). T47D cell cultures and Vero cells were grown on 96 well plates and then incubated for $24 \mathrm{~h}$. After $24 \mathrm{~h}$ the media was removed and washed used PBS, then each concentration of extracts was added into each well with three replications and incubated for $24 \mathrm{~h}$. After $24 \mathrm{~h}$ the media was removed and washed used PBS, then added $100 \mu \mathrm{L}$ MTT reagents (Bio Basic Inc, Canada) to each well, including media control (without cells), then re-incubated for $4 \mathrm{~h}$ in the $\mathrm{CO}_{2}$ incubator.

After $4 \mathrm{~h}$ the cell condition was observed under an inverted microscope, then a $100 \mu \mathrm{L}$ SDS $10 \%$ stopper was added and incubated at room temperature overnight. Furthermore the absorbance value is read using ELISA reader and calculated cell viability using the following formula:

Viability cell $=\frac{(\mathrm{Ta}-\mathrm{Mca})}{(\mathrm{Cca}-\mathrm{Mca})} \times 100 \%$

$\mathrm{Ta}=$ Treatment absorbance; Mca = Media control absorbance; $\mathrm{Cca}=$ Control cell absorbance

The result of viability cell obtained by $\mathrm{IC}_{50}$ analysis for anticancer activity and $\mathrm{CC}_{50}$ analysis for normal cell toxicity using Microsoft Excel (Muti'ah, 2017).

\section{Flowcytometry test}

The cultured T47D cells as much as $5 \times 10^{5}$ cells/well were grown in RPMI medium at 6-well plate (for treatment and control cells) then incubated for $24 \mathrm{~h}$. The cell condition was observed in the microscope to see the cell distribution. Furthermore, the concentration of the sample and doxorubicin was made to the level of $\mathrm{IC}_{50}$. The 6well plate that already contain cells taken from the incubator. Then, the media cell was removed by using a Pasteur pipette slowly and washed with PBS. Furthermore, the treatment conducted by inserting $2 \mathrm{~mL}$ extract samples at the first well (for cell cycle), $2 \mathrm{~mL}$ doxorubicin at the second well, and $2 \mathrm{~mL}$ cell control at the third well and incubated for $24 \mathrm{~h}$. One conical was prepared for one type of treatment or one well. The medium is taken $1 \mathrm{~mL}$ from the well with micropipette and transferred to the conical. To the each well, $1 \mathrm{~mL}$ PBL was added $1 \mathrm{~mL}$ PBS and moved into the conical. The conical was added $200 \mu \mathrm{L}$ of trypsin-EDTA $0.25 \%$ and incubated for $3 \mathrm{~min}$. Furthermore, the wells were added $1 \mathrm{~mL}$ of control media into each well and resuspension until the cells disenganged one by one and the cells are transferred to the conical. The wells are added $2 \mathrm{~mL}$ of PBS to retrieve the remaining cells, then moved into the conical. The conical is centrifuged at $2000 \mathrm{rpm}$ for $5 \mathrm{~min}$ and the supernatant was removed. The each well was washed with $1 \mathrm{~mL}$ PBS again and moved to the conical. The conical is resuspended then moved to microtube. The microtubes were recentrifuged at 2000rpm for $3 \mathrm{~min}$.

In cell cycle analysis, the supernatant is removed by pouring and added $500 \mu \mathrm{L} 70 \%$ alcohol into the conical while shaking slowly. The conical is kept at room temperature $\left(37^{\circ} \mathrm{C}\right)$ for $35 \mathrm{~min}$ and recentrifuged at $600 \mathrm{rpm}$ for $5 \mathrm{~min}$ to removed the added alcohol from the conical. The conical was added $500 \mu \mathrm{L}$ of PBS and centrifuged at 2000rpm for $3 \mathrm{~min}$. The washing was conducted twice used PBS and the conical is wrapped in aluminum foil and marked. For apoptotic analysis, the remained harvest cells was rinsed used PBS then it was centrifuged again and the PBS was removed from the conical. The conical was added of Propidium Iodide reagent and allowed to stand for $30 \mathrm{~min}$. The sludge was added PI-Annexin V reagents carefully and immediately homogenized. The microtube containing the cell suspensions is wrapped in aluminum foil and incubated in a 37C water bath for $5 \mathrm{~min}$. The cells suspension is homogenized and transferred into a flow cytometer tube using a nylon filter to test for cell cycle and cell apoptosis, then ready for analysis with a flow cytometer (CCRC, 2009).

\section{RESULTS AND DISCUSSION}

\section{Identification of $C$. cinerariifolium leaves} extract chemical compound

Chemical compounds identification was conducted to analyze qualitative content and expect phenolic and terpenoid compounds before the cytotoxic and apoptosis to be tested. Thin Layer Chromatography (TLC) is a physicochemical separation method based on two phases, which is a fluid phase as a mobile phase and a solid phase as a stationary phase (Muti'ah et al., 2013). Based on the optimization results showed that the best mobile phase were n-Hexane and ethyl acetate (8:2) as solvents. After elution and air drying of the plate, natural product reagent was sprayed using $10 \%$ $\mathrm{H}_{2} \mathrm{SO}_{4}$ as universal staining. Furthermore, the plate was compared before and after to detection and observed the spots characteristic. The result of TLC visualizer identification used UV 366 rays shows the difference of compound separation between before and after spray (Figure 1). 


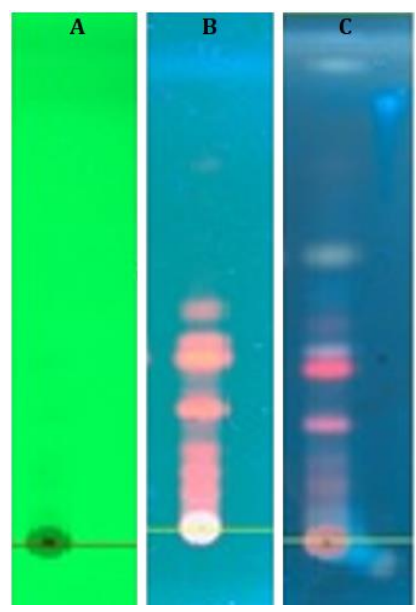

Figure 1. Thin-layer chromatography (TLC) plates of C. cinerariifolium leaves extract stained with $10 \%$ $\mathrm{H}_{2} \mathrm{SO}_{4}$ and visualized under TLC visualizer. A.) Before sprayed under UV $254 \mathrm{~nm}$ rays, B.) Before sprayed under UV $366 \mathrm{~nm}$ rays, C.) After sprayed under white light.

T47D cells treatments
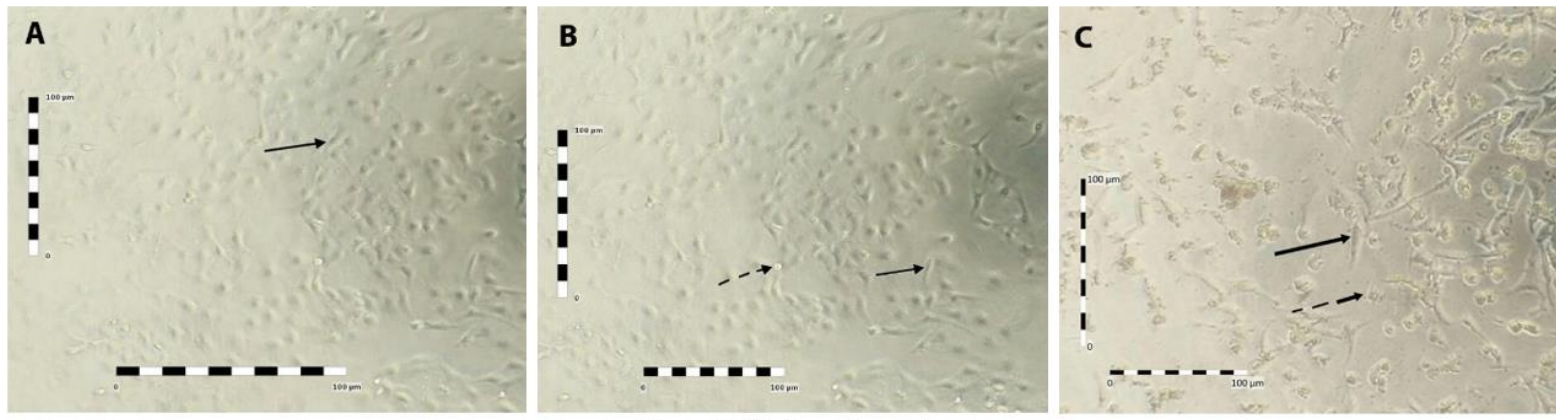

Vero Cells treatments
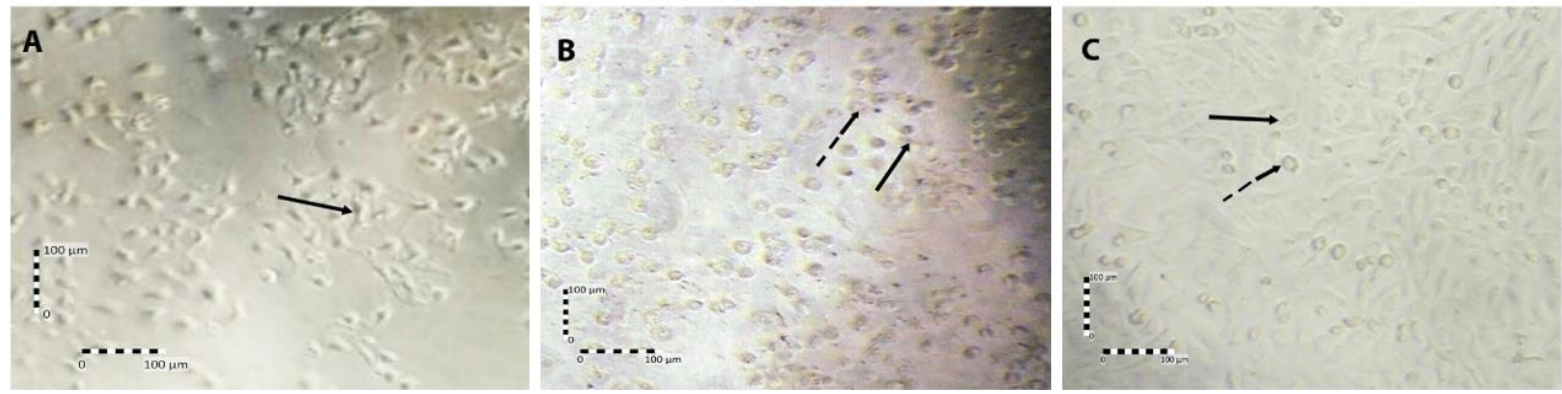

Figure 2. Comparison of inhibitory effect of T47D cell growth and Vero cell after treated with extract $C$. Cinerariifolium and Doxorubicin after 24 hours incubation; (A) Control cells; (B) $135.88 \mu \mathrm{g} / \mathrm{ml}$ Doxorubicin as positive controls; (C) Treated cells used $600 \mu \mathrm{g} / \mathrm{ml}$ leaves extract. Cell morphology was observed under an inverted microscope with magnification 400 times. Alive cells $(\rightarrow)$ and dead cells $(-->)$. Each treatment is repeated three times as triplicate.

It seen in the $\mathrm{Rf}$ results obtained, the $\mathrm{Rf}$ compounds on the TLC plate after spraying more than the Rf value on the TLC plate before spraying. The number of Rf TLC plate on the leaves extract after sprayed is 8.0. The yellow color with wavelength $341-389 \mathrm{~nm}$ after being sprayed showed the flavonol group compound, and the purple, red color showed terpenoid group compounds (Harborne, 1987). Meanwhile, purple 

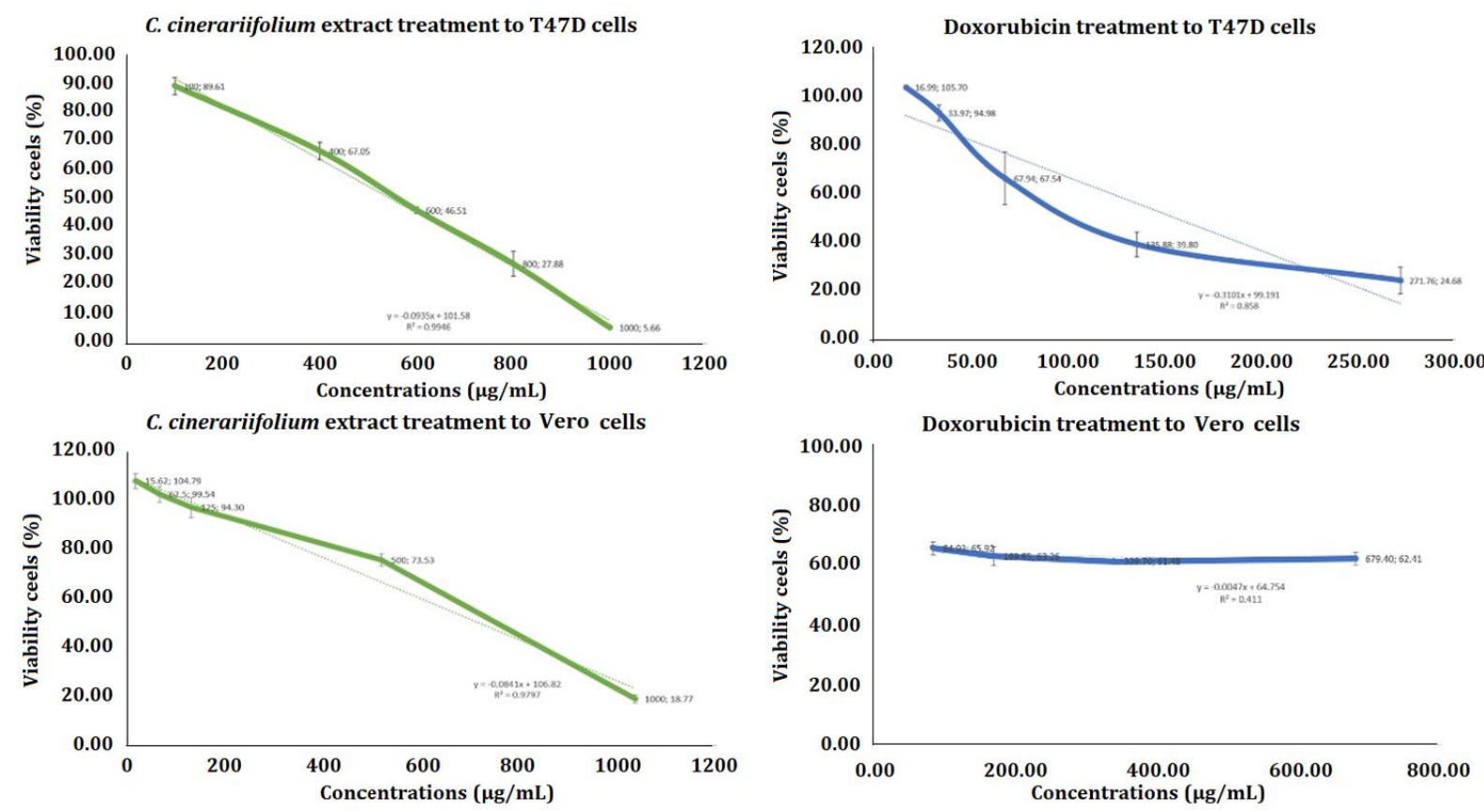

Figure 3. The viability cell using MTT method: Percentage graphic of cell viability in T47D cells after treatment of $C$. cinerariifolium leaves extract (left) and doxorubicin treatment (right). Percentage graphic of cell viability of Vero cells after treatment of $C$. cinerariifolium leaves extract (left) and doxorubicin treatment (right). This data is repeated three times as triplicate and point of each graphic represented the average concentrations.

stains are suspected as sesquiterpenes compounds (Mutiah et al., 2013). Compounds of flavonoids and terpenoid groups play a major role in health, one of which is having anticancer activity in breast cancer (Bishayee et al., 2011; Weeb and Ebeler, 2004).

\section{Cytotoxic test of $C$. cinerariifolium leaves extract} The anticancer activity test of $C$. cinerariifolium leaves extracts known by decreasing living cells percentage based on $50 \%$ Inhibitor Concentration $\left(\mathrm{IC}_{50}\right)$ value. Cell morphological observations conducted under an inverted microscope after treatment on cells with each extract. Comparison of the inhibitory effect of T47D cell growth and Vero cell after treated with extract $C$. cinerariifolium (Figure 2). Morphological change between T47D control cells using the treatment of $C$. cinerariifolium leaves extract and doxorubicin positive control (Figure 2). The form of viable T47D cells was elongated, while the dead T47D cell was shaped rounded shrink (Iin et al., 2014). In Vero cells, there was no apparent cell death due to the treatment of $C$. cinerariifolium leaves extract compared to control. Morphology of viable Vero cells was polygonal and flat (Goncalves, 2012). The treatment of $C$. cinerariifolium leaves extract possesed cytotoxic activity against human cancer cell lines T47D but does exert damage to normal vero cells. To determine the viability of cancer cells due to the treatment of $C$. cinerariifolium extract, then tested the cytotoxicity of T47D cells and Vero cells used the MTT method. The intensity of the purple color that formed is proportional to the number of living cells (Doyle and Griffiths, 2000). The higher the intensity of the purple color indicates a more significant amount of living cells (CCRC, 2009). Percentage of cell viability in T47D and Vero cells due to the treatment of doxorubicin and leaves extract (Figure 3).

\section{Cell cycle due to treatment of $C$. cinerarifolium leaves extract}

Inhibition in the phase of the cell cycle that observed was conducted using flow cytometry method. The flow cytometry method was a method that can detect every phase in the cell cycle based on the number of chromosomes on each phase (G1, S, and G2/M). 

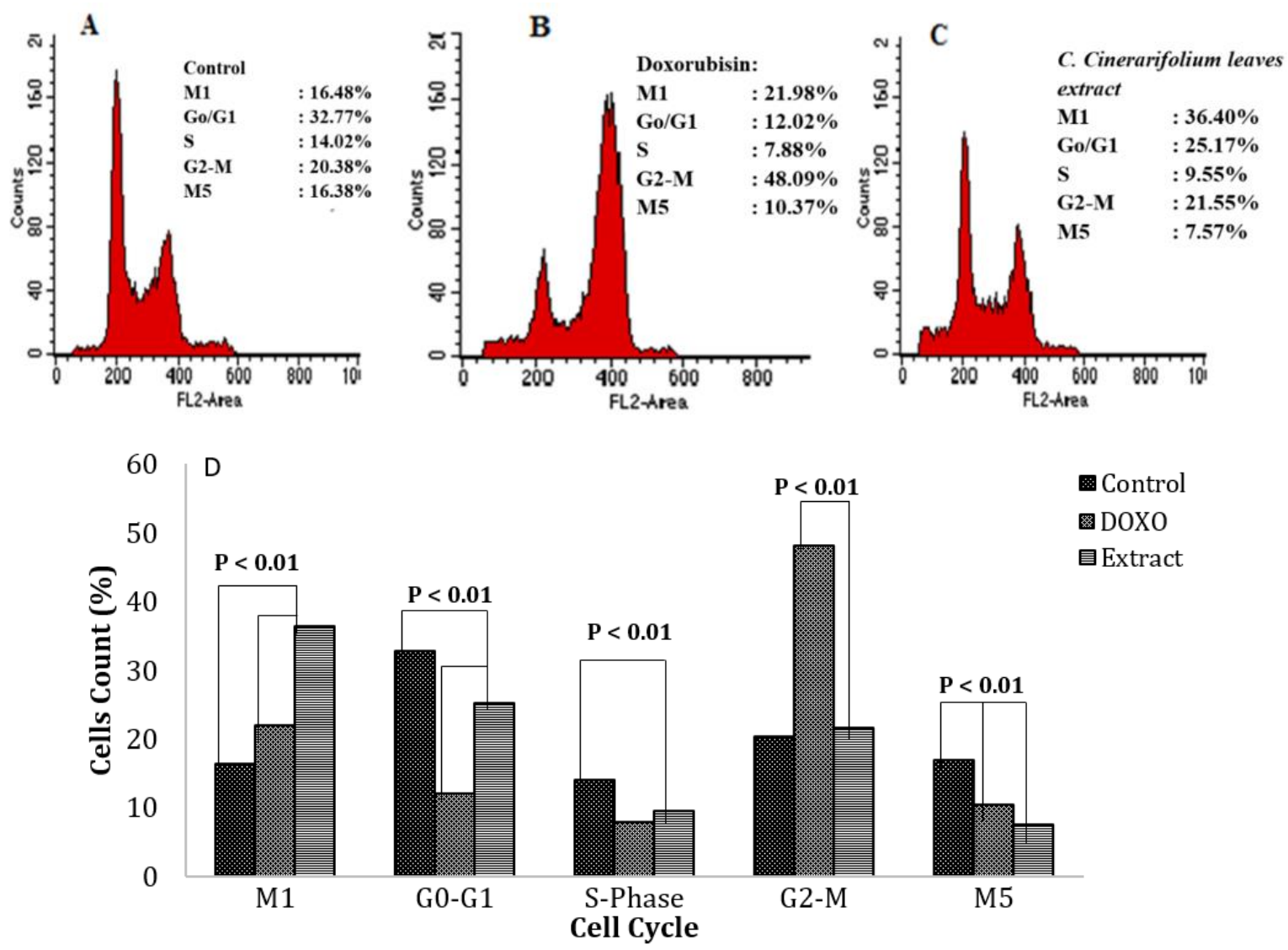

Figure 4. The results of flowcytometry analysis of cell distribution at each phase of cell cycle, A.) control cell, B.) treatment of doxorubicin against T47D cells, C.) treatment of Chrysanthemum cinerariifolium leaves extract on T47D cells D.) graphic of cell cycle distribution.

Through this flow cytometry (Figure 4) method, the distribution of cells at each phase in the cell cycle after treatment could be known. Furthermore, the pathway inhibition of $C$. cinerariifolium leaves extracts in blocking the cell cycle could be estimated.

\section{Apoptosis induction after treating of $C$ cinerariifolium leaves extract}

In flow cytometry test of $C$. cinerariifolium leaves extracted, the $\mathrm{IC}_{50}$ was $418.8 \mu \mathrm{g} / \mathrm{mL}$ and compared with doxorubicin at $\mathrm{IC}_{50} 115.1 \mu \mathrm{g} / \mathrm{mL}$. The results of the apoptotic flowcytometry test against T47D cells (Figure 5). The colors formed in the cell dispersion data were analyzed using a Cell Quest program so that the colors formed can be separated according to the population. Living cells indicated by green, early apoptotic cells exhibited by yellow, late apoptosis indicated by pink, and necrosis indicated by red. The resulting colors obtained from cells that emit epi-fluorescence due to Annexin V or PI bonds which are then captured by UV rays (Indradmojo, 2015).

Anticancer activity on T47D and Vero cell and the effects of $C$. cinerariifolium leaves extract on apoptosis induction and regulation of breast cancer cycle T47D conducted as the purpose of this study. $\mathrm{IC}_{50}$ result obtained from $C$. cinerariifolium leaves extract was $418.8 \mu \mathrm{g} / \mathrm{mL}$, while $\mathrm{IC}_{50}$ doxorubicin result was $115.1 \mu \mathrm{g} / \mathrm{mL}$ (Figure 3). The results of $\mathrm{IC}_{50}$ obtained showed that $96 \%$ ethanol leaves extract of $C$. cinerariifolium to have anticancer activity against breast cancer (T47D). An extract has high anticancer activity if $\mathrm{IC}_{50}<500 \mu \mathrm{g} / \mathrm{mL}$ and has weak activity if $\mathrm{IC}_{50}>500 \mu \mathrm{g} / \mathrm{mL}$ (Costa et al., 2017). The $\mathrm{IC}_{50}$ result in positive control equal to $115.1 \mu \mathrm{g} / \mathrm{mL}$ and these result obtained was close to IC $_{50}$ researchers that $\mathrm{IC}_{50}$ doxorubicin value against T47D cells is $250 \mathrm{nM}$ or $135.9 \mu \mathrm{g} / \mathrm{mL}$ (Abdolmohammadi, 2008). 

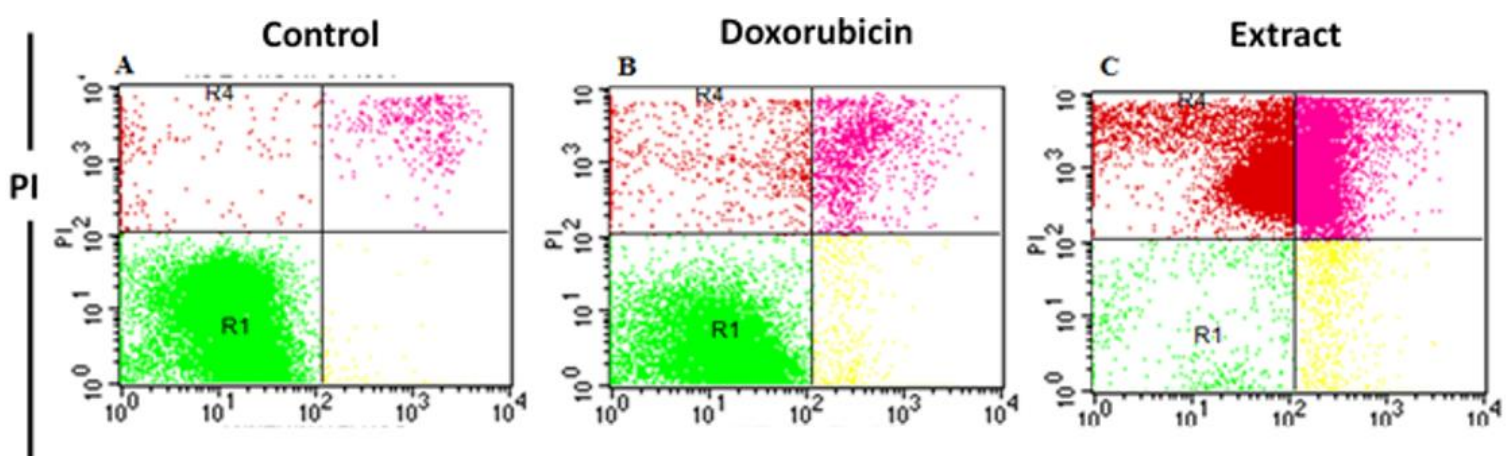

Annexin V-FITC

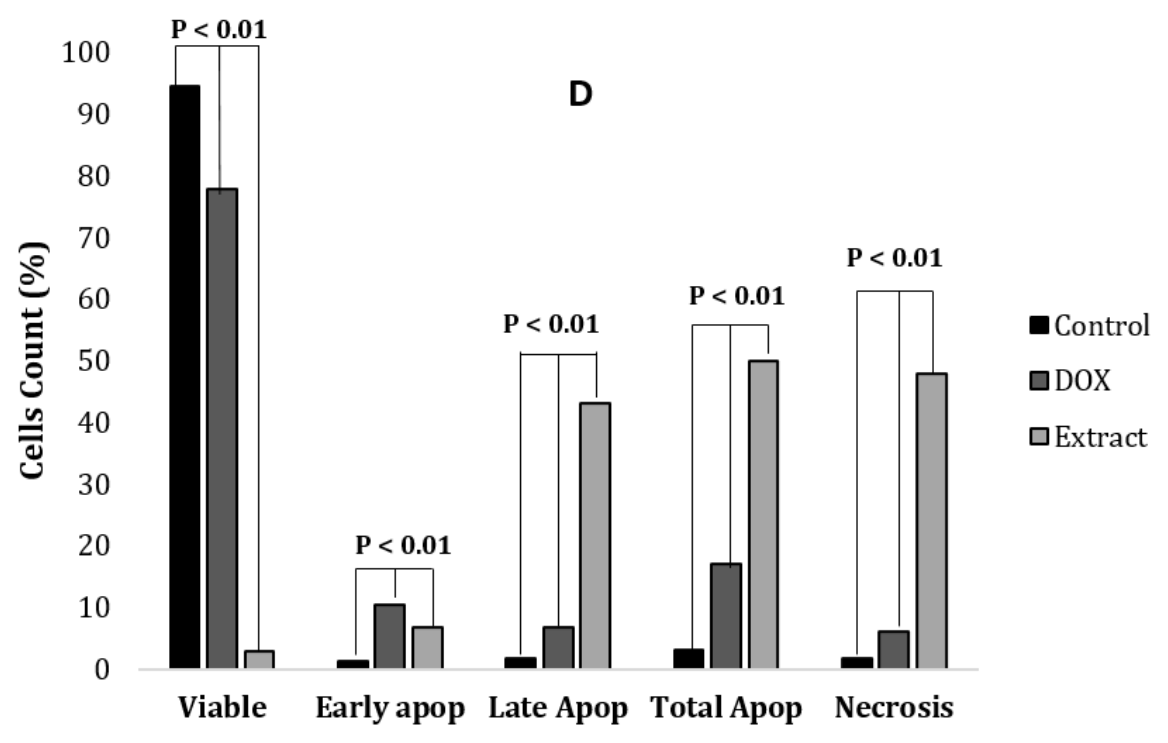

Figure 5. Result of flowcytometry of apoptotic test against T47D cell A.) control cell, B.) treatment used doxorubicin, C.) C. cinerariifolium leaves extract, D.) Comparison graphic of T47D cell population using LSD analysis.

Doxorubicin has a low $\mathrm{IC}_{50}$ result because it has high activity against breast cancer cells (Anjarsari, 2013). The results of cytotoxic activity test on Vero cell (Figure 3 ) that obtained from IC $_{50}$ showed that $96 \%$ ethanol leaves extract of $C$. cinerariifolium has low toxicity to normal cells. The result of $\mathrm{IC}_{50}$ leaves extract of $C$. cinerariifolium in Vero cell was $676.182 \mu \mathrm{g} / \mathrm{mL}$, while IC $_{50}$ doxorubicin value was $1234.5 \mu \mathrm{g} / \mathrm{mL}$. The low toxicity of normal cells in vitro tests correlates with high levels of safety against normal cells (Mutiah et al., 2017).

Percentage analysis of the viability of living cells, apoptosis, and necrosis showed untreated cells (cell control) had a cell viability percentage of $94.47 \%, 3 \%$ apoptotic cells, and $1.82 \%$ necrosis cells (Figure 5). While doxorubicin-treated cells showed a decrease in cell viability to $77.78 \%$, an increase in apoptosis by $17.13 \%$, and an increase in the number of necrosis by $5.18 \%$ when compared with control cells. However, based on the percentage of cell viability when compared with the rate of apoptosis and necrosis cells, the percentage of living cells still more significant than dead cells. It might because doxorubicin was able to increase the activity of phosphorylation of $\mathrm{P} 13 \mathrm{~K} / \mathrm{Akt}$ then activate $\mathrm{Bcl}$ protein which is an antiapoptosis protein and could activate Bad protein which is a protein trigger apoptosis (Setiawati, 2011).

In the treatment of ethanol leaves extract of C. cinerariifolium showed that T47D cell apoptosis induction was $49.88 \%$ and necrosis was $47.29 \%$, and the living cell was $2.83 \%$ (Figure 4). The result of statistical analysis of three treatments showed a significant difference 
between apoptosis percentage on cell control, after treatment of doxorubicin, and after treatment of C.cinerariifolium leaves extract with the considerable $p$-value $(p<0.01)$. The results of the statistical analysis of the percentage of cell necrosis also showed similar results. The flow cytometry analysis conducted used cell quest program (Figure 5). Cell distribution in each phase of the cell cycle was colored used PI reagents as it was able to interact with DNA (Putri, 2014). Based on Figure 5 there was changed in the cell cycle between the $C$. cinerariifolium leaves extract and control cells that indicated by the reduction in cell numbers in the G0-G1 phase and S phase. These reductions meant the cessation of the cell. While in phase M1, the control cell was increased which indicates the presence of apoptotic cell death. Therefore, the cell may couldn't proceed to the next phase (Mutiah et al., 2017). Doxorubicin led to cellular inhibition in the G0-G1 phase but pointed to the cell shift to the right at the G2-M phase indicating that the cell enters the phase (Mutiah, 2014). Accumulation cells in the G2-M phase causes the down regulation of Cdc24c, Cdk1, amd Cyclin B (Su, et al., 2006). Inhibiting Cdc2/Cyclin B is one of the result in the effect of ATM-ATR signaling, causing G2-M arrest (Kolb, et al., 2012).

The increase of apoptosis by $C$. cinerariifolium leaves extract suspected due to the content of flavonoid compounds. Flavonoid compounds could induce apoptosis through p53 pathways. If flavonoids induce apoptosis through irreversible DNA damage, then apoptosis was possible through the p53 pathway (Meiyanto and Septisetyani, 2005). Anticancer activity of $C$. cinerariifolium leaves extract suspected by the mechanism of the flavonoid compounds contained in the leaves extract of $C$. cinerariifolium. Flavonoid compounds can inhibit the overall performance of CDK which is a cell cycle regulator. Inhibition that occurs through the working of enzymes CDKactivating kinase then could inhibit the formation of active CDK-cyclin complex (Supriatno and Rasmindar, 2014). Proteins that could inhibit the CDK-cyclin complex were INK4 and CIP (p21). INK4 plays a role in inhibiting progression in G1 phase. When a G1 phase occurs, the cell automatically cannot proceed to the next phase (Mutiah, 2014).

\section{CONCLUSION}

In conclusion, the results of the present study reveal that ethanol leaves extract of $C$. cinerariifolium could induce $49.88 \%$ T47D cell apoptosis at IC50 $418.8 \mu \mathrm{g} / \mathrm{mL}$ concentration, and could inhibit cell cycle in phase G0-G1 and S phase and increased cell number in phase M1. The flavonoid compounds that content in $C$. cinerariifolium supposed could induce apoptosis through p53 pathways. The ability of $C$. cinerariifolium ethanol leaves extracts to induce apoptosis to suggest that it could be a new candidate of anticancer therapy.

\section{ACKNOWLEDGEMENT}

This work supported by The Directorate General of Islamic Higher Education (DIKTIS) of Interdisciplinary Basic Research Grant numbers 3209/Un.3/HK.00.5/05/2018.

\section{REFERENCES}

Abdolmohammadi MH., Fouladdel SH., Shafiee A., Amin GH., Ghaffari SM., Azizi E. 2008. Anticancer Effects and Cell Cycle Analysis on Human Breast Cancer T47D Cells Treated with Extracts of Astrodaucus persicus (Boiss.) Drude in Comparison to Doxorubicin. Journal Daru, 16:112-118.

Alviana N., Sidharta BR., Martini T. 2016. Test the effectiveness of antibacterial ethanol extract of Chrysanthemum of green (Chrysanthemum morifolium Syn. Dendrathema grandiflora) against Staphylococcus aureus and Escherichia coli. Yogyakarta: Universitas Atma Jaya Yogyakarta.

Anjarsari EY., Kristiani N., Larasati YA., Dewi D., Putri P, Meiyanto E. 2013. Synergistic Effect of Cinnamon Essential Oil (Cinnamomum burmannii) and Doxorubicin on T47D Cells Correlated with Apoptosis Induction. IJCC. 450-456.

Bishayee A., Ahmed S., Brankov N., Perloff M. 2011. Triterpenoids as Potential agents for the Chemoprevention and Therapy of Breast Cancer. Front Biosci, 16: 980-996.

Cancer Chemoprevention Research Center (CCRC). 2009. Prosedur Tetap Perhitungan Sel. Yogyakarta: Fakultas Farmasi UGM, http://ccrc.farmasi.ugm.ac.id/wpcontent/uploads/03.006.-Perhitungan-sel; [accessed 13 March 2017].

Costa EVS., Brigido HPC., Silva JVDS., Ferreira MRC., Brandao GC., Dolabela MF. 2017. Anti leishmanial Activity of Handroanthus serratifolius (Vahl) S. Grose (Bignoniaceae). Evidence-Based Complementary and Alternative Medicine Hindawi, 1:1-6. 
DeSantis C., Ma J., Bryan L., Jemal A. 2013. Breast cancer statistics, 2013. A Cancer Journal for Clinicians, 64:52-62.

Doyle A., Griffiths JB. Cell and Tissue Culture for Medical Research. New York: John Willey and Sons Ltd 2000.

Goncalves D. 2012. The Micro-analysis of Human Burned Bones: Some Remarks. Cadernos do GEEvH, 1:32-40.

Grdisa M., Carovic-Stanko K., Kolak I., Satovic Z., 2009. Morphogical and Biochemical Diversity of Dalmatian Pyrethrum (Tanacetum cinerariifolium (Trevir.) Sch.Bip.). Agriculturae Conpectus Scientificus, 74(2):73-80.

Harborne JB. 1987. Phytochemical Methods Guide Modern ways to analyse plants. Bandung : ITB .

Iin T., Andrew J., Kisdjamiatun. 2014. In Vitro toxicity of ethanolic acid fruit Parijoto (Medinilla speciosa, reinw.ex bl.) against breast cancer cells T47D. Jurnal Gizi Indonesia, 2:53-58.

Indradmojo C. 2015. Anti-cancer activities and pharmacological mechanisms of extracts and Benalu Nangka fraction (Macrosolen cochinchinensis) in breast cancer cells T47. Malang: UIN Maulana Malik Ibrahim Malang. Jeong SW., Park S., Jin JS., Seo ON., Kim GS., Kim YH., et al., 2012. Influences of Four Different Light-Emitting Diode Lights on Flowering and Polyphenol Variations in the Leaves of Chrysanthemum (Chrysanthemum morifolium). J Agric Food Chem, 60:97939800.

Kim Y., Han J., Sung J., Lee J. 2012. Antiinflammatory activity of Chrysanthemum zawadskii var. latilobum leaf extract through haem oxygenase-1 induction. Journal of Functional Foods, 4:474-479.

Kolb RH., Greer PM., Cao PT., Cowan KH., Yan Y. 2012. ERK1/2 signaling plays an important role in topoisomerase II poison-induced G2/M checkpoint activation. PLoS One. 7(11):e50281.

Meiyanto E, Septisetyani EP. 2005 Antiproliferative effects and Apoptosis of phenolic extract of etanolic leaves Gynura procumberns (Lour.) Merr. Against HeLa cells. Artocarpus, 5:1-12.

Muti'ah R. 2017. Study of efficacy and safety of extracts of root and leaf Calotropis gigantea against colon cancer cells and breast cancer in Vitro cells. J Islamic Med, 2:67-75.
Mutiah R., Listiyana A., Indradmojo C., Griana TP., Dwi HH., Atmaja RR. 2017. Induction of Apoptosis and Phase-Cell Cycle Inhibition of G0-G1, S, G2-M of T47D Breast Cancer Cells on Treatment with Ethyl Acetate Fraction of Jackfruit Parasite Leaves (Macrosolen cochinensis). Journal of Applied Pharmaceutical Science, 7:138-143.

Mutiah R., Hayati EK, Triastutik Y. 2013. Separation and identification of sunflower leaf extract (Helianthus annus L.) used thin layer chromatography. Alchemy, 2:190-194.

Mutiah R., Widyawaruyanti A, Sukardiman. 2018. Calotroposid A: A Glycosides Terpenoids from Calotropis gigantea Induces Apoptosis of Colon Cancer WiDr Cells through Cell Cycle Arrest G2/M and Caspase 8 Expression. Asian Pacific Journal of Cancer Prevention, 19:1457-1464.

Mutiah., R. 2014. Development of Phytopharmacy and anticancer (guidelines and techniques for development of Indonesian Herbal medicine into Phytofarmaka). Malang: UIN Maliki Press.

Octavia Y., Tocchetti CG., Gabrielson KL., Janssens S., Crijins HJ., Moens AL. 2012. Doxorubicininduced cardiomyopathy: From molecular mechanisms to therapeutics strategies. J Mol Cell Cardiology, 52(6):1213-1225.

Putri H. 2014. Sample preparation for cell cycle by Flowcytometry method. Yogyakarta: Cancer Cemoprevention Research Center Pharmacy Faculty Gadjah Mada University.

Sari M., Dewi YI., Utami A. 2017. Family support relationship to the motivation of breast cancer patients in a chemotherapy in the room of Cendrawasih 1 RSUD Arifin Achmad Riau Province. J Ners Indonesia, 2:158-166.

Setiawati S., Meiyanto E. 2011. Increased cytotoxic effect of Doxorubicin by Hesperidin in cancer cells T47D. Bionatura-Jurnal IlmuIlmu Hayati dan Fisik, 15:85-92.

Su,CC., Lin, JG., Li TM., Chung JG. Yang JS. et al., 2006 Curcumin-induced apoptosis of human colon cancer COLO-205 cells through the production of ROS, Ca2+ and the activation of caspase 3. Anticancer Res. 26, 4379-4389

Supriatno AH, Rasmindar M. 2014. Anticancer and antiproliferation activity of ant-nest ethanol fraction (Myrmecodya pendans) in human tongue cancer SP-CI. Dentofasial, 13:1-6.

Ukiya M., Akhisa T., Tokuda H., Suzuki H., Mukainaka T., et al., . 2002. Constituents of Compositae plants III. Anti-tumor promoting 
effects and cytotoxic activity against human cancer cell lines of triterpene diols and triols from edible chrysanthemum flowers. Cancer Letters, 177(1):7-12

Weeb MR, Ebeler SE. 2004. Comparative Analysis of Topoisomerase IB Inhibition and DNA Intercalation by Flavonoids and Similiar
Compounds: Structural Determinates of Activity. Biochem J. 527-541.

Yerlikaya PO., Arisan ED., Gurkan AC., Unsu NP. 2017. Breast Cancer and Flavonoids as Treatment Strategy. From Biology to Medicine, 2:305-326. 